\title{
Pengaruh Pemberian Tuntunan Penyelesaian Latihan Soal dalam Pembelajaran Langsung Terhadap Pemahaman Konsep Mol Pada Siswa Kelas X MIPA MAN Kota Palangka Raya Tahun Ajaran 2018/2019
}

The Effect of Giving Guidelines for Questionnaire Completion in Direct Learning on the Understanding of the Mole Concept in Class X MIPA MAN Students in Palangka Raya City 2018/2019 Academic Year

\author{
Fitriani $^{1)}$, Abudarin $^{2)}$, Karelius ${ }^{3)}$ \\ ${ }^{1,2}$ Pendidikan Kimia, Jurusan Pendidikan MIPA/FKIP - Universitas Palangka Raya \\ Palangka Raya - Indonesia 73111 \\ ${ }^{3}$ Kimia, FMIPA - Universitas Palangka Raya, Palangka Raya - Indonesia 73111 \\ *E-mail: lovefitriani2@gmail.com
}

\begin{abstract}
Abstrak
Banyak siswa yang mengalami kesulitan dalam memahami konsep mol. Berdasarkan hal tersebut, tujuan penelitian ini adalah untuk mendeskripsikan pengaruh pemberian tuntunan penyelesaian latihan soal dalam pembelajaran langsung terhadap pemahaman konsep mol pada siswa kelas X MIPA MAN Kota Palangka Raya tahun ajaran 2018/2019. Penelitian ini merupakan penelitian kuantitatif, pada penelitian melibatkan siswa kelas X MIPA MAN Kota Palangka Raya sebanyak 62 siswa. Instrumen yang digunakan berupa tes I, tes II, dan latihan soal dengan tuntunan penyelesaian. Hasil uji statistik menggunakan uji-t menunjukkan bahwa thitung $(1,72)$ lebih besar dari tabel $(1,67)$ pada taraf signifikan $5 \%$, artinya terdapat pengaruh terhadap pemahaman konsep mol hasil pembelajaran langsung menggunakan latihan soal dengan tuntunan penyelesaian pada siswa kelas X MIPA MAN Kota Palangka Raya Tahun Ajaran 2018/2019. Rata-rata nilai tes II kelas eksperimen $(82,67)$ lebih tinggi dari kelas kontrol $(77,50)$.
\end{abstract}

Kata kunci: Konsep mol, latihan soal, pemahaman konsep, pengaruh

\begin{abstract}
Many students have difficulty understanding the concept of the mole. Based on this, the purpose of this study is to describe the effect of providing guidance on completing practice questions in direct learning on understanding the concept of mole in class $X$ MIPA MAN Palangka Raya City 2018/2019 academic year. This research is a quantitative research, the research involved 62 students of class X MIPA MAN Palangka Raya City. The instruments used were test I, test II, and practice questions with completion guidance. The results of statistical tests using the t-test show that the t-test (1.72) is greater than the table (1.67) at a significant level of $5 \%$, meaning that there is an influence on the understanding of the concept of the mole concept of direct learning using exercise questions with completion guidance in class X students. MIPA MAN City of Palangka Raya for the 2018/2019 Academic Year. The mean score of the experimental class II test (82.67) was higher than the control class (77.50).
\end{abstract}

Keywords: Mole Concept, Problem Practice, Concept Understanding, Influence 


\section{PENDAHULUAN}

Ilmu kimia merupakan salah satu cabang IPA yang mempelajari materi dan perubahannya. Jutaan materi yang berbeda banyak terdapat di alam, sehingga dikatakan bahwa ilmu kimia adalah salah satu ilmu pemahaman dan rekayasa materi. Salah satu materi dalam ilmu kimia yang penting adalah stoikiometri. Konsep-konsep dasar yang dipelajari dalam stoikiometri, meliputi massa atom relatif, massa molekul relatif, konsep mol, dan tetapan Avogadro. Konsep-konsep tersebut bersifat abstrak, berjenjang, dan saling berkaitan sehingga menjadi penyebab siswa mengalami kesulitan dalam memahami stoikiometri. Salah satu materi yang dipelajari dalam stoikiometri adalah konsep mol.

Konsep mol merupakan pengetahuan konseptual berbasis ide. Penerapan konsep mol berkaitan dengan jumlah partikel, massa zat, dan volume gas (STP) merupakan pengetahuan prosedural yang lebih efektif dipelajari menggunakan suatu latihan soal. Penelitian yang dilakukan oleh Sari (2014) menunjukkan bahwa penggunaan LKS-Latihan Soal Terstruktur berpengaruh positif terhadap pemahaman konsep tetapan kesetimbangan kimia (Kc dan Kp) pada siswa kelas XI IPA 1 SMA Muhammadiyah 1 Palangka Raya yakni dapat meningkatkan pemahaman siswa. Berdasarkan hasil penelitian tersebut, pembelajaran yang menggunakan LKS-Latihan Soal Terstruktur dapat membuat siswa aktif dalam mengikuti pembelajaran sehingga mampu meningkatkan pemahaman siswa.

Mol adalah banyaknya suatu zat yang mengandung entitas dasar (atom, molekul, atau partikel lain) sebanyak jumlah atom yang terdapat dalam 12 gram (atau $0,012 \mathrm{~kg}$ ) isotop karbon-12. Jumlah atom sebenarnya didalam $12 \mathrm{~g}$ karbon-12 ditentukan melalui percobaan. Jumlah ini disebut bilangan Avogadro (NA) dengan nilai NA = 6,02 $\times 1023$.

Cara belajar yang paling efektif dalam menentukan konsep mol adalah dengan menggunakan latihan-latihan soal, sebelum siswa mengerjakan latihan-latihan soal, siswa harus mengetahui konsep dan langkah-langkah dalam mengerjakan soal tersebut. Latihan-latihan soal yang dapat digunakan oleh siswa untuk berlatih dan belajar biasanya telah dikemas oleh guru dalam bentuk tuntunan latihan soal.

Penggunaan tuntunan latihan soal dirancang sedemikian rupa sehingga dapat memudahan siswa dalam menyelesaikan soal-soal, tuntunan latihan soal ini memuat langkah-langkah penyelesaian soal yang dibuat secara sistematis, termasuk petunjuk dan arahan yang memudahkan siswa dalam menyelesaikan soal. Tuntunan latihan soal cocok digunakan untuk pengetahuan yang bersifat prosedural, agar dapat memantau, membimbing, dan meningkatkan pemahaman siswa. Argumen itu telah dibuktikan dalam penelitian-penelitian terdahulu. Hal ini dianggap efektif dan mampu membantu membimbing siswa dalam belajar, serta memudahkan siswa dalam memahami materi yang bersifat prosedural. Berdasarkan uraian tersebut maka rumusan masalah yang tepat adalah apakah pemberian tuntunan penyelesaian latihan soal dalam pembelajaran langsung terhadap pemahaman konsep mol berpengaruh pada siswa kelas X MIPA MAN kota Palangka Raya tahun ajaran 2018/2019. 


\section{BAHAN DAN METODE}

Metode penelitian yang digunakan dalam penelitian ini adalah metode eksperimen, karena dalam penelitian ini dilakukan suatu percobaan dengan memberikan perlakuan-perlakuan dan membandingkan pengaruhpengaruh perlakuan tersebut terhadap suatu sampel yang dipilih. Penelitian ini, kelas eksperimen mendapatkan perlakuan khusus, sedangkan kelas kontrol tidak mendapatkan perlakuan khusus. Kemudian dibandingkan hasil akhir, dalam penelitian ini kelas eksperimen diberikan tuntunan latihan soal sedangkan kelas kontrol diberikan latihan soal tanpa tuntunan.

Populasi dalam penelitian ini adalah semua siswa kelas X Semester II di MAN Kota Palangka Raya yang terdiri dari lima kelas yaitu kelas X MIPA-1, kelas X MIPA-2, kelas X MIPA-3, kelas X MIPA-4, dan kelas X MIPA-5. Sedangkan sampel dalam penelitian ini dipilih secara acak dua kelas sebagai sampel, yaitu kelas eksperimen (kelas X MIPA-1) dan kelas kontrol (kelas X MIPA-3).

Teknik pengumpulan data yang digunakan dalam penelitian ini berupa tes esai. Adapun tahap-tahap yang digunakan dalam pengumpulan dan pengolahan data yaitu:

\section{a. Tahap I}

Pada tahap ini kedua sampel (kelas eksperimen dan kelas kontrol) diberikan pembelajaran langsung. Selanjutnya, diberikan tes I untuk mengukur kemampuan awal siswa terhadap materi pelajaran yang akan diberikan pada saat perlakuan. Hasil prasyarat kemudian dibandingkan dengan melihat skor rata-rata kelas.

b. Tahap II

Pada tahap ini kelas yang berperan sebagai kelas eksperimen diajarkan dengan menggunakan tuntunan penyelesaian latihan soal dalam pembelajaran langsung. Sementara kelas kontrol diajarkan dengan pembelajaran yang sama, tetapi tanpa tuntunan penyelesaian. Baik kelas eksperimen maupun kelas kontrol diberikan materi yang sama dan jumlah jam belajarnya juga sama.

c. Tahap III

Tahap ini adalah tahap pengukuran penguasaan materi oleh siswa. Pengukuran ini diberikan dengan pemberian tes II, pada kedua kelas yaitu kelas eksperimen dan kelas kontrol. Serta data yang diperoleh kemudian dianalisis dengan teknik analisis data penelitian.

Data yang diperoleh dianalisis dengan data tes I didapat sebelum perlakuan dan data tes II didapat setelah diberikan perlakuan. Kemudian, dapat dilihat ada atau tidak adanya peningkatan pemahaman konsep siswa setelah menggunakan tuntunan penyelesaian latihan soal dalam pembelajaran langsung pada siswa kelas eksperimen dan pembelajaran tanpa tuntunan penyelesaian latihan soal dalam pembelajaran langsung pada kelas kontrol.

Pemeriksaan hasil tes setiap siswa dilakukan dengan memberi skor pada lembar jawaban. Langkah selanjutnya adalah menjumlahkan skor yang diperoleh masing-masing siswa dan mengkonversikan dalam bentuk nilai dengan rumus sebagai berikut.

$$
\text { Nilai }=\frac{\text { jumlah skor } \text { yang diperoleh siswa }}{\text { jumlah skor maksimal }} \times 100 \%
$$

Prasyarat Uji Analisis dilakukan, sebelum diberikan perlakuan terlebih dahulu dilakukan uji keseimbangan untuk mengetahui apakah data tes I 
kelas eksperimen dan kelas kontrol seimbang. Data tersebut dilakukan uji normalitas untuk mengetahui normal atau tidaknya distribusi pada kelas eksperimen dan kelas kontrol dan uji homogenitas untuk menentukan rumus uji-t yang digunakan. Selanjutnya dilakukan uji hipotesis yaitu untuk mengetahui apakah terdapat pengaruh atau tidak dalam penelitian ini. Untuk menguji hipotesis tersebut digunakan uji-t dengan rumus:

$$
t=\frac{\bar{x}_{1}-\bar{x}_{2}}{\sqrt{\frac{\left(n_{1}-1\right) s_{1}^{2}+\left(n_{2}-1\right) s_{2}^{2}}{n_{1}+n_{2}-2}\left(\frac{1}{n_{1}}+\frac{1}{n_{2}}\right)}}
$$

Kriteria: pada $\mathrm{db}=\left(\mathrm{n}_{2}+\mathrm{n}_{1}-2\right)$ dan taraf signifikan 5\%

1. Jika harga $\mathrm{t}_{\text {hitung }} \leq \mathrm{t}_{\text {tabel }}$, maka $\mathrm{H}_{0}$ diterima dan $\mathrm{H}_{\mathrm{a}}$ ditolak

2. Jika harga $\mathrm{t}_{\text {hitung }}>\mathrm{t}_{\text {tabel }}$, maka $\mathrm{H}_{0}$ ditolak dan $\mathrm{H}_{\mathrm{a}}$ diterima

\section{HASIL dan PEMBAHASAN}

a. Deskrispsi Pelaksanaan Penelitian

Sebelum pengambilan data, terlebih dahulu dilakukan simulasi pembelajaran di MAN Kota Palangka Raya kelas X MIPA-3 pada hari Kamis, 11 April 2019 sebagai kelas kontrol dan kelas X MIPA-1 pada hari Sabtu, 13 April 2019 sebagai kelas eksperimen.

b. Perbedaan Pemahaman Konsep Siswa pada Setiap Indikator

Perbedaan pemahaman konsep siswa pada setiap indikator didasarkan pada data hasil tes I dan tes II. Persentase data pemahaman konsep siswa pada setiap indikator dapat dilihat pada tabel berikut.

\begin{tabular}{|c|c|c|c|c|c|}
\hline \multirow{3}{*}{ Indikator } & \multirow{3}{*}{$\begin{array}{l}\text { Nom } \\
\text { or } \\
\text { Butir } \\
\text { Soal }\end{array}$} & \multicolumn{4}{|c|}{ Pemahaman Konsep (\%) } \\
\hline & & \multicolumn{2}{|c|}{$\begin{array}{c}\text { Kelas } \\
\text { Eksperimen } \\
\end{array}$} & \multicolumn{2}{|c|}{ Kelas Kontrol } \\
\hline & & Tes I & Tes II & Tes I & Tes II \\
\hline $\begin{array}{l}\text { Menghitung jumlah mol } \\
\text { berdasarkan hubungan } \\
\text { jumlah mol dengan } \\
\text { jumlah partikel }\end{array}$ & 1 & 56,67 & 86,67 & 65,62 & 86,46 \\
\hline $\begin{array}{l}\text { Menghitung jumlah } \\
\text { partikel berdasarkan } \\
\text { hubungan jumlah mol } \\
\text { dengan jumlah partikel }\end{array}$ & 2 & 51,11 & 82,22 & 55,21 & 76,04 \\
\hline $\begin{array}{l}\text { Menghitung jumlah mol } \\
\text { berdasarkan hubungan } \\
\text { jumlah mol dengan } \\
\text { jumlah massa zat }\end{array}$ & 3 & 28,33 & 78,33 & 31,67 & 78,12 \\
\hline $\begin{array}{l}\text { Menghitung massa zat } \\
\text { berdasarkan hubungan } \\
\text { jumlah mol dengan } \\
\text { massa zat }\end{array}$ & 4 & 18,33 & 73,33 & 21,88 & 76,56 \\
\hline $\begin{array}{l}\text { Menghitung jumlah mol } \\
\text { berdasarkan hubungan } \\
\text { jumlah mol dengan } \\
\text { volume gas (STP) }\end{array}$ & 5 & 48,89 & 91,11 & 40,62 & 79,17 \\
\hline $\begin{array}{l}\text { Menghitung volume gas } \\
\text { berdasarkan hubungan } \\
\text { jumlah mol dengan } \\
\text { volume gas (STP) }\end{array}$ & 6 & 38,89 & 87,78 & 33,33 & 68,75 \\
\hline Rata-rata Indikator & & 40,37 & 83,24 & 41,39 & 77,52 \\
\hline
\end{tabular}


Tabel menunjukkan bahwa persentase pemahaman konsep siswa pada setiap indikator, rata-rata persentase pemahaman pada tes II kelas eksperimen lebih tinggi daripada persentase pemahaman pada kelas kontrol. Jika dilihat dari tes II kelas eksperimen dan kelas kontrol nilainya tidak teralu jauh berbeda, ini karena keterbatasan penelitian. Pada pengambilan data kelas eksperimen dilakukan perlakuan terlebih dahulu dengan jarak waktu beberapa hari dari kelas kontrol, kemungkinan ada interaksi dari kelas eksperimen dan kelas kontrol.

c. Data Hasil Analisis

Tabel 1. Uji Normalitas Data Nilai Tes I Kelas Eksperimen dan Kelas Kontrol

\begin{tabular}{lccccc}
\hline $\begin{array}{c}\text { Data Nilai } \\
\text { Tes I }\end{array}$ & $\mathbf{N}$ & $\boldsymbol{\alpha}$ & $\chi_{\text {hitung }}^{2}$ & $\chi_{\text {tabel }}^{2}$ & \multirow{2}{*}{ Kesimpulan } \\
\hline Eksperimen & 30 & 0,05 & 3,80 & 11,07 & \multirow{2}{*}{ Normal } \\
\hline Kontrol & 32 & 0,05 & 0,90 & 11,07 & \\
\hline
\end{tabular}

Tabel 2. Uji Homogenitas Data Nilai Tes I Kelas Eksperimen dan Kelas Kontrol

\begin{tabular}{lcccc}
\hline $\begin{array}{c}\text { Data Nilai } \\
\text { Tes I }\end{array}$ & Varians & $\mathbf{F}_{\text {hitung }}$ & $\mathbf{F}_{\text {tabel }}$ & Kesimpulan \\
\cline { 1 - 2 } Ekperimen & 146,44 & 1,21 & 1,848 & Homogen \\
\hline Kontrol & 177,99 & 1,21 &
\end{tabular}

Tabel 3. Data Nilai Rata-rata Tes I dan Standar Deviasi Kelas Eksperimen dan Kelas Kontrol

\begin{tabular}{ccc}
\hline \multirow{2}{*}{ Kelas } & \multicolumn{2}{c}{ Data Nilai Tes I } \\
\cline { 2 - 3 } & Rata-rata & Standar Deviasi \\
\hline Eksperimen & 38,67 & 12,10 \\
\hline Kontrol & 39,53 & 13,34 \\
\hline
\end{tabular}

Tabel 4. Uji Normalitas Data Nilai Tes II Kelas Eksperimen dan Kelas Kontrol

\begin{tabular}{lccccc}
\hline $\begin{array}{c}\text { Data Nilai Tes } \\
\text { II }\end{array}$ & $\mathbf{N}$ & $\boldsymbol{\alpha}$ & $\chi_{\text {hitung }}^{2}$ & $\chi_{\text {tabel }}^{2}$ & \multirow{2}{*}{ Kesimpulan } \\
\hline Eksperimen & 30 & 0,05 & 4,14 & 11,07 & \multirow{2}{*}{ Normal } \\
\hline Kontrol & 32 & 0,05 & 1,88 & 11,07 & \\
\hline
\end{tabular}

Tabel 5. Uji Homogenitas Data Nilai Tes II Kelas Eksperimen dan Kelas Kontrol

\begin{tabular}{ccccc}
\hline Data Nilai Tes II & Varians & $\mathbf{F}_{\text {hitung }}$ & $\mathbf{F}_{\text {Tabel }}$ & Kesimpulan \\
\hline Ekperimen & 116,78 & \multirow{2}{*}{1,57} & 1,848 & \multirow{2}{*}{ Homogen } \\
\hline Kontrol & 183,87 & & &
\end{tabular}

Tabel 6. Data Rata-rata Nilai Tes II dan Standar Deviasi Kelas Eksperimen dan Kelas Kontrol

\begin{tabular}{ccc}
\hline \multirow{2}{*}{ Kelas } & \multicolumn{2}{c}{ Data Nilai Tes II } \\
\cline { 2 - 3 } & Rata-rata & Standar Deviasi \\
\hline Eksperimen & 82,67 & 10,81 \\
\hline Kontrol & 77,50 & 13,56 \\
\hline
\end{tabular}

\section{d. Uji Hipotesis}

Hipotesis dalam penelitian ini diuji kebenarannya menggunakan uji-t. Pengujian hipotesis pada penelitian ini menggunakan data nilai tes II dari kelas eksperimen dan kelas kontrol. 


$$
\begin{aligned}
& t_{\text {hitung }}=\frac{\overline{\mathrm{x}}_{1}-\overline{\mathrm{x}}_{2}}{\sqrt{\frac{\left(\mathrm{n}_{1}-1\right) \mathrm{s}_{1}^{2}+\left(\mathrm{n}_{2}-1\right) \mathrm{s}_{2}^{2}}{\mathrm{n}_{1}+\mathrm{n}_{2}-2}\left(\frac{1}{\mathrm{n}_{1}}+\frac{1}{\mathrm{n}_{2}}\right)}} \\
& =\frac{82,67-77,50}{\sqrt{\frac{(30-1)(116,78)+(32-1)(183,87)}{30+32-2}\left(\frac{1}{30}+\frac{1}{32}\right)}} \\
& =\frac{5,17}{\sqrt{\frac{3.386,678+6.187,507}{60}\left(\frac{1}{30}+\frac{1}{32}\right)}} \\
& =\frac{5,17}{\sqrt{\frac{9.086,679}{60}(0,06)}} \\
& =\frac{5,17}{\sqrt{151,445(0,06)}} \\
& =\frac{5,17}{\sqrt{9,09}} \\
& =\frac{5,17}{3,01} \\
& =1,72
\end{aligned}
$$

Hipotesis yang diuji adalah sebagai berikut:

$\mathrm{H}_{0}=$ Pemberian tuntunan penyelesaian latihan soal dalam pembelajaran langsung tidak berpengaruh terhadap pemahaman konsep mol pada siswa kelas X MIPA MAN Kota Palangka Raya Tahun Ajaran 2018/2019.

$\mathrm{H}_{\mathrm{a}}=$ Pemberian tuntunan penyelesaian latihan soal dalam pembelajaran langsung berpengaruh terhadap pemahaman konsep mol pada siswa kelas X MIPA MAN Kota Palangka Raya Tahun Ajaran 2018/2019.

Berdasarkan perhitungan uji-t data nilai tes II kedua kelas sampel diperoleh $\mathrm{t}_{\text {hitung }}=1,72$ sedangkan $\mathrm{t}_{\text {tabel }}=1,67$ pada taraf signifikan $5 \%$ dan $\mathrm{dk}=\mathrm{n}_{1}+\mathrm{n}_{2}$ $-2=30+32-2=60$, karena $t_{\text {hitung }}>t_{\text {tabel }}$ maka $\mathrm{H}_{0}$ ditolak dan $\mathrm{H}_{\mathrm{a}}$ diterima. Berdasarkan hasil uji tersebut, dapat disimpulkan bahwa pemberian tuntunan penyelesaian latihan soal dalam pembelajaran langsung berpengaruh terhadap pemahaman konsep mol pada siswa kelas X MIPA MAN Kota Palangka Raya Tahun Ajaran 2018/2019.

e. Analisis Pengaruh Pemberian Tuntunan Penyelesaian Latihan Soal pada Kelas Eksperimen dan Kelas Kontrol

Pemahaman konsep mol pada siswa kelas eksperimen setelah pembelajaran menggunakan latihan soal dengan tuntunan penyelesaian dan pemahaman konsep mol pada siswa kelas kontrol setelah menggunakan latihan soal tanpa tuntunan penyelesaian, dapat dilihat dengan menganalisis setiap tahapan hasil jawaban siswa berdasarkan indikator yang ingin dicapai pada kelas eksperimen maupun kelas kontrol masing-masing terdiri dari 6 butir soal esai pada tes I dan tes II, yang merupakan tes pemahaman konsep. Indikator pencapaian siswa antara lain: 1) menghitung jumlah mol berdasarkan hubungan jumlah mol dengan jumlah partikel, 2) menghitung jumlah partikel berdasarkan hubungan jumlah mol dengan jumlah partikel, 3) menghitung jumlah mol berdasarkan hubungan jumlah mol dengan massa 
zat, 4) menghitung massa zat berdasarkan hubungan jumlah mol dengan massa zat, 5) menghitung jumlah mol berdasarkan hubungan jumlah mol dengan volume gas (STP) dan, 6) menghitung volume gas berdasarkan hubungan jumlah mol dengan volume gas (STP).

Analisis perbedaan pemahaman konsep siswa bertujuan untuk membandingkan kemampuan siswa kelas eksperimen setelah pembelajaran menggunakan latihan soal dengan tuntunan penyelesaian dengan siswa kelas kontrol setelah pembelajaran menggunakan latihan soal tanpa tuntunan penyelesaian. Jawaban siswa yang dianalisis adalah jawaban siswa kelompok atas dan kelompok bawah pada kelas ekperimen dan kelas kontrol. Siswa yang termasuk kelompok atas atau kelompok bawah ditentukan berdasarkan nilai keseharian setelah pembelajaran ketika saya mengajar PPL-2 semester ganjil tahun ajaran 2018/2019 di MAN Kota Palangka Raya. Jumlah siswa yang dilibatkan pada pengambilan data tes yaitu 30 dan 32 siswa, maka diambil masing-masing sebanyak $27 \%$ dari kelompok atas dan kelompok bawah untuk keperluan analisis.

\section{SIMPULAN}

Berdasarkan hasil uji statistik menggunakan uji-t menunjukkan bahwa pembelajaran langsung menggunakan latihan soal dengan tuntunan penyelesaian berpengaruh terhadap pemahaman konsep mol pada siswa kelas X MIPA MAN Kota Palangka Raya Tahun Ajaran 2018/2019. Ratarata pemahaman konsep siswa yang belajar menggunakan latihan soal dengan tuntunan penyelesaian pada tes II $(82,67)$ lebih tinggi dari siswa yang belajar menggunakan latihan soal tanpa tuntunan penyelesaian $(77,50)$. Berdasarkan hasil penelitian ini dapat disarankan bahwa pembelajaran langsung menggunakan latihan soal dengan tuntunan penyelesaian dalam pembelajaran kimia dapat dijadikan salah satu alternatif pilihan untuk meningkatkan pemahaman konsep siswa. Namun, guru harus menyesuaikan dengan materi pelajaran, yaitu materi yang penyelesaiannya menggunakan perhitungan. 


\section{REFERENSI}

Akbar, Sa'dun. 2016, Instrumen Perangkat Pembelajaran. Bandung: PT Remaja Rosdakarya Offset.

Amalia, Firda. 2018, Perbedaan Pemahaman Konsep pH Larutan Penyangga Asam Hasil Pembelajaran Langsung Menggunakan LKS Latihan Soal Terstruktur dan Latihan Soal pada Siswa Kelas XI IPA SMA Negeri 4 Palangka Raya Tahun Ajaran 2017/2018. Skripsi Sarjana, tidak diterbitkan. Universitas Palangka Raya.

Atkins, P. W. 1996, Kimia Fisika Edisi Keempat Jilid 1. Jakarta: Erlangga.

Dahar, R,W. 2011, Teori-Teori Belajar dan Pembelajaran. Jakarta: Erlangga.

Depdiknas. 2008, Panduan Pengembangan Bahan Ajar. Jakarta: Departemen Pendidikan Nasional Direktorat Pendidikan Dasar dan Menengah.

Depdiknas. 2008, Lembar Kerja Siswa (student worksheet). Jurnal Pendidikan Matematika Hal. 30-34.

Emzir. 2013, Metodologi Penelitian Pendidikan. Depok: PT Raja Grafindo Persada.

Hidayati, Lusiana. 2018, Perbedaan Pemahaman Konsep Pengaruh Ion Senama dan pH Larutan Terhadap Kelarutan Hasil Pembelajaran Langsung Menggunakan LKS-Latihan Soal Terstruktur dan Latihan Soal tak Terstruktur pada Siswa Kelas XI MIPA MAN Kota Palangka Raya Tahun Ajaran 2017/2018. Skripsi Sarjana, tidak diterbitkan. Universitas Palangka Raya.

Indahsari, Eli Nur. 2019, Perbedaan Pemahaman Konsep Tata Nama Senyawa Alkana Hasil Pembelajaran Langsung Menggunakan LKS-Latihan Soal Terstruktur dan LKS-Latihan Soal pada Siswa Kelas XI IPA SMA Negeri 4 Palangka Raya Tahun Ajaran 2018/2019. Skripsi Sarjana, tidak diterbitkan. Universitas Palangka Raya.

Indrawan, R dan Yaniawati, P. 2016, Metodologi Penelitian. Bandung: PT Refika Aditama.

Kamus Tinggi Bahasa Indonesia. http://kbbi.web.id/pola. Pengertian-Pengaruh. Diakses pada 20 Desember 2018.

Kountur, Ronny. 2009, Metode Penelitian. Jakarta: Buana Printing.

Majid, Abdul. 2005, Perencanaan Pembelajaran. Bandung: PT Remaja Rosdakarya Offset.

Pasini Mairing, Jackson. 2017, Statistika Pendidikan Konsep \& Penerapannya Menggunakan Minitab dan Micsrosoft Excel. Yogjakarta: Penerbit ANDI.

Qodratilah, M. T. (2011), Kamus Bahasa Indonesia untuk Pelajar. Jakarta: Badan Pengembangan dan Pembinaan Bahasa.

Rachamawati, Tutik, dan Daryanto. 2015, Teori Belajar dan Proses Pembelajaran yang Mendidik. Yogyakarta: Gava Media.

Rahardjo, Sentot, B. dan Ispriyanto. 2013, Buku Siswa Kimia Berbasis Eksperimen. Solo: Tiga Serangkai.

Sari, Nia, L. 2014, Pengaruh Penggunaan LKS-Penyelesaian Soal Terstruktur Terhadap Pemahaman Konsep Tetapan Kesetimbangan Kimia (Kc dan Kp) Pada Siswa Kelas XI IPA 1 SMA Muhammadiyah 1 Palangka Raya Tahun Ajaran 2013/2014. Skripsi Sarjana, tidak diterbitkan. Universitas Palangka Raya.

Sidauruk, Adelina, P. 2015, Kesulitan Siswa Memahami Konsep Mol Di Kelas XI IPA SMA Negeri 2 Palangka Raya, SMA Negeri 4 Palangka Raya, dan SMA Negeri 6 Palangka Raya Pada Tahun Ajaran 2014/2015 (Studi Kasus). Skripsi Sarjana, tidak diterbitkan. Universitas Palangka Raya.

Sugiyono. 2010, Metode Penelitian Pendidikan. Bandung: Alfabeta. 
Suhana, Cucu. 2014, Konsep Strategi Pembelajaran. Bandung: PT Refika Aditama.

Sukmadinata, Nana, S. 2015, Metode Penelitian Pendidikan. Bandung: PT Remaja Rosdakarya.

Sunarya, Yayan. 2000, Kimia Dasar 1. Bandung: Alkemi Grafisindo Press.

Trianto. 2010, Model Pembelajaran Terpadu. Jakarta: PT Bumi Aksara.

Uno, Hamzah, B. 2006, Perencanaan Pembelajaran. Jakarta: PT Bumi Aksara.

Yunita, Dwi. 2014, Peningkatan Pemahaman Konsep Ikatan Kovalen dengan Menggunakan LKS Latihan Soal Terstruktur pada Siswa Kelas X SMA Negeri 1 Sanaman Mantikei Tumbang Kaman Tahun Ajaran 2013/2014. Skripsi Sarjana, tidak diterbitkan. Universitas Palangka Raya.

Yusuf, Muri. 2016, Metode Penelitian. Jakarta: Prenamedia Group. 